\title{
A combined phase I/lla study of the safety, bronchodilator and bronchoprotective effects of nebulized RPL554, a dual PDE3/4-inhibitor, in healthy subjects and asthmatics
}

\author{
Luigi Franciosi ${ }^{1}$, Zuzana Diamant ${ }^{2 *}$, Nicoletta Morelli ${ }^{3}$, Marieke de $\mathrm{Kam}^{4}$, Adam Cohen ${ }^{3}$, Michael Walker ${ }^{5}$, \\ Clive Page ${ }^{6}$
}

From EAACI International Severe Asthma Forum (ISAF 2012)

Gothenburg, Sweden. 11-13 October 2012

\section{Rationale}

RPL554 is a novel dual phosphodiesterase (PDE) 3 and 4 isoenzymes inhibitor that has been demonstrated to have both potent, long-acting bronchodilator and antiinflammatory activity in preclinical models.

\section{Objectives}

To evaluate the safety, bronchodilator and bronchoprotective effects of single ascending doses of RPL554 in healthy subjects and asthmatics.

\section{Methods}

The safety of RPL554 0.003 and $0.009 \mathrm{mg} / \mathrm{kg}$ was evaluated in 18 healthy males (age 18-41 years; weight 58-90 $\mathrm{kg}$; height $168-196 \mathrm{~cm}$; BMI $18-29 \mathrm{~kg} / \mathrm{m}^{2}$ ) in a randomised, double-blind study. For each dose group, 6 subjects inhaled RPL554 and 3 placebo. Study medication was administered by a calibrated electronic nebuliser and oronasal mask. Subsequently, RPL554 0.009 and $0.018 \mathrm{mg} / \mathrm{kg}$ were evaluated in 6 asthmatic males (22-29 years; 58-98 $\mathrm{kg}$; $174-198 \mathrm{~cm}$; BMI $19-27 \mathrm{~kg} / \mathrm{m}^{2}$, FEV1 75-118\% pred.) using an open, adaptive design to select an effective dose. This dose $(0.018 \mathrm{mg} / \mathrm{kg})$ was further evaluated in a randomised, double-blind, placebo-controlled, cross-over study in 10 allergic asthmatics (20-50 years; 67-112 kg; 171-191 $\mathrm{cm}$; BMI $21-33 \mathrm{~kg} / \mathrm{m}^{2}$, FEV1 $82-112 \%$ pred.; baseline $\mathrm{PC} 20$ (methacholine $=\mathrm{MCh}$ ) $0.07-1.49 \mathrm{mg} / \mathrm{ml}$; not on controller medication) to assess its bronchodilator effects and

\footnotetext{
${ }^{2}$ University Medical Centre Groningen, General Practice, the Netherlands Full list of author information is available at the end of the article
}

bronchoprotective activity against methacholine (MCh) challenge.

\section{Results}

Inhaled RPL554 0.003 to $0.018 \mathrm{mg} / \mathrm{kg}$ was well-tolerated in all subjects studied. In the asthmatics, RPL554 0.018 $\mathrm{mg} / \mathrm{kg}$ produced a rapidly progressive, sustained bronchodilation with a mean maximal increase in FEV1 of $520 \mathrm{ml}$ (95\% CI: $320-720 \mathrm{ml} ; \mathrm{p}=0.0061$ ), or $15 \%$ increase from baseline. Furthermore, a single dose of RPL554 increased PC20 (MCh) by a mean of 1.46 doubling doses (95\% CI: $0.63-2.28 ; \mathrm{p}=0.004)$ versus placebo. Adverse events were mild, transient and generally of equal frequency in RPL554 and placebo treated groups. No significant changes in heart rate or systemic blood pressure were noted with RPL554 when compared to placebo.

\section{Conclusions}

RPL554 was well-tolerated in the healthy subjects and asthmatics studied. In patients with mild asthma, a rapid, potent and long-lasting bronchodilator response was produced. The maximum bronchodilator effect appeared at least comparable to published values of inhaled salbutamol. RPL554 has the potential to become a first-in-class bronchodilator for airways obstruction.

\footnotetext{
Author details

${ }^{1}$ Verona Pharma Plc, Clinical Research, UK. ${ }^{2}$ University Medical Centre Groningen, General Practice, the Netherlands. ${ }^{3}$ Centre for Human Drug Research (CHDR), Clinical Research, the Netherlands. ${ }^{4}$ Centre for Human Drug Research (CHDR), Statistics, the Netherlands. ${ }^{5}$ University of British Columbia, Anesthesiology, Pharmacology and Therapeutics, Canada. 'King's College London, Sackler Institute of Pulmonary Pharmacology, UK.
} 
doi:10.1186/2045-7022-3-S1-013

Cite this article as: Franciosi et al:: A combined phase 1/lla study of the safety, bronchodilator and bronchoprotective effects of nebulized RPL554, a dual PDE3/4-inhibitor, in healthy subjects and asthmatics. Clinical and Translational Allergy 2013 3(Suppl 1):013.

Submit your next manuscript to BioMed Central and take full advantage of:

- Convenient online submission

- Thorough peer review

- No space constraints or color figure charges

- Immediate publication on acceptance

- Inclusion in PubMed, CAS, Scopus and Google Scholar

- Research which is freely available for redistribution

Submit your manuscript at www.biomedcentral.com/submit
Ciomed Central 